\title{
Quality Evaluation of Soy-mumu Supplemented with Moringa Leaf Powder
}

\author{
Shar Faustina Mbanengen, Igbabul Bibiana Dooshima*, Ikya Julius, Dabels Nanyen
}

Department of Food Science and Technology, University of Agriculture, Makurdi, Nigeria

\author{
Email address: \\ bibideke@yahoo.com (B. D. Igbabul) \\ ${ }^{*}$ Corresponding author
}

\section{To cite this article:}

Shar Faustina Mbanengen, Igbabul Bibiana Dooshima, Ikya Julius, Dabels Nanyen. Quality Evaluation of Soy-mumu Supplemented with Moringa Leaf Powder. Journal of Food and Nutrition Sciences. Vol. 4, No. 5, 2016, pp. 131-135. doi: 10.11648/j.jfns.20160405.13

Received: September 10, 2016; Accepted: September 23, 2016; Published: October 15, 2016

\begin{abstract}
The effect of moringa leaf powder supplementation on some quality characteristics of Soy-mumu was determined. Soy-mumu was prepared from composite flours of $85: 15,75: 15,70: 15$ and 65:15\% roasted maize flour and roasted soy-bean flour respectively and supplemented with 0,10,15 and 20\% Moringa leaf powder respectively. The Soy-mumu samples were then analysed for proximate composition, minerals, vitamin A and sensory characteristics. The addition of Moringa leaf powder to soy-mumu resulted to significant difference $(\mathrm{P}<0.05)$ in the proximate composition; moisture content decreased significantly $(\mathrm{P}<0.05)$ with increase in the addition of Moringa leaf powder from 10.40 to $9.34 \%$ and significant decrease $(\mathrm{P}<$ 0.05 ) in the carbohydrate content of the products from 65.71 to $50.27 \%$ with increase in the addition of Moringa leaf powder. Minerals and vitamin A content increased significantly $(\mathrm{P}<0.05)$ with increase in Moringa leaf powder supplementation. Sensory evaluation results showed that the acceptability of the samples decreased with increase in the level of Moringa leaf powder supplementation.
\end{abstract}

Keywords: Soy-mumu, Moringa Leaf Powder, Quality

\section{Introduction}

Muтu is a traditional cereal-based food product in Nigeria, particularly consumed by Tiv people in Benue State. The product is produced from maize, sorghum or millet and consumed by both adults and children [1]. The need to provide a protein rich food led to the production of soy-mumu which is produced by blending maize with soybean [1]. Blending of maize with soy-bean results to a product of higher nutritional value in terms of protein but low in micronutrient content [1]. There is therefore the need for further research in supplementing soy-mumu with the locally available micronutrient plant sources.

Moringa is an important food commodity that has had enormous attention as the natural nutrition of the tropic. The leaves are completely safe for consumption because they have neither known negative effects, nor toxic elements and is good source of protein, vitamin A, B and C and minerals such as calcium and iron [2]. The micronutrient content is even more in dried leaves containing $1 / 2$ the vitamin $\mathrm{C}$ of orange, seventeen (17) times the calcium of milk; fifteen (15) times the potassium of bananas; nine (9) times the protein of yoghurt; twenty-five (25) times the vitamin A of carrots and twenty-five (25) times the iron of spinach [3-4]

Thus blending Soy-mumu with Moringa leaf powder could significantly improve the nutritional value of the product especially in terms of its micronutrient contents thereby improving the nutritional status of the consumers.

\section{Materials and Methods}

\subsection{Sources of Raw Materials}

White Maize (Zea mays) and light yellow variety of soybeans (Glycinemax) were purchased from North Bank Market, Makurdi. Matured Moringa oleifera leaves were obtained from Moringa trees on University of Agriculture, Makurdi farms. 


\subsection{Samples Preparation}

\subsubsection{Preparation of Roasted Maize Flour}

Roasted maize flour was prepared according to the method described by [1] with slight modification, without fermentation of the grains. Maize grains were sorted and winnowed to remove grain stalk, sticks and remaining cob parts. The grains were further subjected to visual screening to remove foreign particles such as stones. This was followed by washing with water to remove dust, soil particles and any over floats. Damaged, diseased or discoloured grains as well as immature or sprouted grains were discarded. Cleaned maize grains were cooked in two times water $(1: 2 \mathrm{w} / \mathrm{v})$ for $45 \mathrm{~min}$, allowed to cool and drained of excess water for $15 \mathrm{~min}$. prepared maize grains were oven roasted at $150^{\circ} \mathrm{C}$ for $60 \mathrm{~min}$. The roasted grains were kept under silica gel to avoid moisture re-absorption until when required for milling and mixing for formulation of blends. A hammer mill was used to mill the roasted grains and a sieve of $0.5 \mathrm{~mm}$ was attached to collect the milled product.

\subsubsection{Preparation of Roasted Soybean Flour}

Soybeans for supplementation were prepared by the methods described by [1]. Dry whole soy- beans were soaked overnight in tap water solution of $0.5 \% \mathrm{NaHCO}_{3}(1: 3 \mathrm{w} / \mathrm{v})$ after sorting and washing. After soaking, the beans were dehulled, tied loosely in bags of fine muslin and blanched at $100^{\circ} \mathrm{C}$ for 30 minutes in fresh tap water solution of $0.5 \%$ $\mathrm{NaHCO}_{3}$ (1:3 bean: solution ratio). The blanched beans were drained and further rinsed with tap water and held for 1hour in order to allow for moisture equilibration within the beans. This was followed by drying at $60^{\circ} \mathrm{C}$ for 6 hours in accordance with the method described by [1] for the production of roasted soybeans. Dry roasting was achieved by use of air-oven instead of coffee roasters as reported by [1]. The soy- beans were browned at $150^{\circ} \mathrm{C}$ for 30 minutes. The roasted soybeans were cooled and stored under silica gel in a desicator (to avoid moisture absorption) until when required for milling and mixing. A hammer mill was used to mill the roasted soy-beans and a sieve of $0.5 \mathrm{~mm}$ was attached to collect the milled product.

\subsubsection{Preparation of Moringa Leaf Powder}

The Moringa Leaf powder was prepared according to the methods described by [4]. About $1 \mathrm{~kg}$ of Matured and fresh Moringa leaves were plucked from the Moringa tree. Diseased and damaged leaves were discarded manually just after collection of the fresh leaves. Collected leaves were washed in trough using clean potable water to remove dirt. Washed leaves were soaked in 1\% Saline solution (Sodium Chloride) for 5 minutes to remove microbes and finally rinsed in clean potable water. The washed leaves were drained of excess water by spreading them on perforated trays for 15 minutes before taking them for drying. The washed and drained Moringa leaves were dried by spreading them on sterile clean net mesh in a well-ventilated room (at an ambient temperature of $30^{\circ} \mathrm{C}$ ) for a drying period of 16 days with frequent turning with hand to ensure uniform drying. Crushing of the dried Moringa leaves was carried out using mortar and pestle and sieved using $0.5 \mathrm{~mm}$ sieve screen. The sieved powder was then packaged in air-tight plastic containers and stored at ambient temperature $\left(30^{\circ} \mathrm{C}\right)$ until when needed for blending.

\subsection{Formulation of Blends}

Four different blends, A, B, C and D were formulated using different ratios: sample A was comprising $85 \%$ roasted maize flour, $15 \%$ roasted soy-bean flour and $0 \%$ Moringa leaf powder which served as the control; sample B comprising $75 \%$ roasted maize flour, $15 \%$ roasted soy-bean flour and 10\% Moringa leaf powder; sample $\mathrm{C}$ comprising $70 \%$ roasted maize flour, $15 \%$ soy-bean flour and $15 \%$ Moringa leaf powder and sample D comprising 65\% roasted maize flour, $15 \%$ roasted soy-bean flour and 20\% Moringa leaf powder as shown in Table 1.

Table 1. Formulation of blends from roasted maize flour, roasted soy-bean flour and Moringa leaf powder.

\begin{tabular}{llll}
\hline Sample & $\begin{array}{l}\text { \%Roasted } \\
\text { maize flour }\end{array}$ & $\begin{array}{l}\text { \% Roasted } \\
\text { Soy-bean flour }\end{array}$ & $\begin{array}{l}\text { \% Moringa } \\
\text { leaf Powder }\end{array}$ \\
\hline A (control) & 85 & 15 & 0 \\
B & 75 & 15 & 10 \\
C & 70 & 15 & 15 \\
D & 65 & 15 & 20 \\
\hline
\end{tabular}

\section{Analyses}

\subsection{Determination of Proximate Composition of Soy-mumu Supplemented with Moringa Powder}

Moisture content, ash, crude fibre, protein and fat were determined by the method of Association of Official Analytical chemists [5], while carbohydrates was determined by difference according to [6].

\subsection{Determination of Mineral Elements and Vitamin Aof Soy-mumu Supplemented with Moringa Powder}

Mineral elements (Iron, Iodine, Zinc, Calcium and Sodium) were determined using Atomic Absorption Spectrophotometre (AA800 Perkin-Elmer, Germany) as described by [5].Vitamin A was determined according to methods described by [7]. All assays were performed in triplicate.

\subsection{Sensory Evaluation of Soy-mumu Supplemented with Moringa Powder}

Sensory evaluation of the four different blends of SoyMumu was carried out according to a method described by [8] using eighteen-member panellists consisting of students and staff members of Food Science and Technology Department, University of Agriculture, Makurdi. The product from each blend was presented in coded plastic plate. The order of presentation of sample to the panel was randomized. 
Potable water was provided for panellists to rinse mouth between evaluations. The panellists were instructed to evaluate the coded samples by indicating their likeness for aroma, taste, colour, texture and overall acceptability on a 9point Hedonic Scale where 9=like extremely; $8=$ like very much; $7=$ like moderately; $6=$ like slightly; $5=$ neither like nor dislike; $4=$ dislike slightly; $3=$ dislike moderately; $2=$ dislike very much and $1=$ dislike extremely.

\subsection{Statistical Analyses}

Data from the sensory evaluation, proximate composition, mineral and vitamin A contents were analyzed using analysis of Variance and least significant difference $(\mathrm{P}<0.05)$ as described by [9].

\section{Results and Discussion}

\subsection{Proximate Composition of Soy-mumu Supplemented with Moringa Powder}

The addition of Moringa leaf powder to soy-mumu resulted to significant difference $(\mathrm{P}<0.05)$ in the proximate composition; moisture content decreased significantly $(\mathrm{P}<$ $0.05)$ with increase in the addition of Moringa leaf powder from 10.40 to $9.34 \%$. This could be due to low moisture content of the Moringa leaf powder used in the blends.

There was significant decrease $(\mathrm{P}<0.05)$ in the carbohydrate content of the products from 65.71 to $50.27 \%$ with increase in the addition of Moringa leaf powder.

This could be as result of dilution effect by Moringa leaf powder which has a carbohydrate content of 38.20\% [10-11].

Lower carbohydrate content was also reported by [12] when eight multi-mixes were formulated as complementary foods from processed soybeans, cowpeas, maize, sorghum, yams, cocoyam, plantain and sweet potatoes in the ratio of $65 \%$ cereal, $30 \%$ legume and $5 \%$ starch staple.

The crude fat, protein ash and crude fibre increased significantly $(\mathrm{P}<0.05)$ from 3.65 to $5.28 \% ; 17.40$ to $26.25 \%$; 1.60 to $3.20 \%$ and 2.30 to $4.60 \%$ respectively as the percentage of Moringa leaf powder addition increased. This is similar to the reports received from studies by [13] in which cereal based -product (maize-ogi) was supplemented with other food substances; okra seed meal. A similar trend was observed by [14] in attempt to formulate low- cost nutritive complementary foods by using malted maize, millet and sorghum with groundnut and soybean. Similar observation was reported by [10] when wheat bread was produced with wheat/Moringa leaf powder blends. These results also agree with the results obtained by [11] whereby fortification of maize-ogi with moringa leaf powder led to significant increase in the protein content of the product from 9.0\% ( $0 \%$ supplementation) to 17.63 (15\% supplementation).

These changes in the nutritional value of the Soy-mumu products may be attributed to the relatively higher fat, protein, ash and crude fibre contents of the moringa leaves compared to the non-supplemented Soy-mumu product.

Table 2. Proximate Composition of Soy-Mumu supplemented with moringa powder (g/100g).

\begin{tabular}{|c|c|c|c|c|c|c|}
\hline Sample & Moisture & Crude protein & Crude fat & Ash & Crude fibre & Carbohydrate \\
\hline $\mathrm{A}$ & $10.4^{\mathrm{a}}$ & $17.4^{\mathrm{b}}$ & $3.6^{\mathrm{c}}$ & $1.6^{\mathrm{c}}$ & $2.3^{\mathrm{c}}$ & $64.7^{\mathrm{a}}$ \\
\hline B & $9.8^{\mathrm{b}}$ & $18.5^{\mathrm{a}}$ & $3.7^{\mathrm{c}}$ & $3.0^{\mathrm{b}}$ & $4.3^{b}$ & $61.8^{\mathrm{b}}$ \\
\hline $\mathrm{C}$ & $9.4^{\mathrm{c}}$ & $26.2^{c}$ & $4.7^{\mathrm{b}}$ & $3.2^{\mathrm{a}}$ & $4.6^{\mathrm{a}}$ & $52.9^{c}$ \\
\hline $\mathrm{D}$ & $9.3^{c}$ & $26.3^{c}$ & $5.2^{\mathrm{a}}$ & $3.2^{\mathrm{a}}$ & $4.6^{\mathrm{a}}$ & $51.3^{\mathrm{d}}$ \\
\hline L.S.D & 0.2040 & 0.3092 & 0.2525 & 0.1353 & 0.1938 & 0.5011 \\
\hline
\end{tabular}

Values are means \pm S.D triplicate determinations. Means within each column not followed by the same superscript letters are significantly $(\mathrm{P}<0.05)$ different.

Key:

$\mathrm{A}=85 \%$ Roasted maize flour: $15 \%$ Roasted Soy-bean flour: $0 \%$ Moringa leaf powder.

$\mathrm{B}=75 \%$ Roasted maize flour: $15 \%$ Roasted Soy-bean flour: $10 \%$ Moringa leaf powder

$\mathrm{C}=70 \%$ Roasted Maize flour: 15\%Roasted Soy-bean flour: $15 \%$ Moringa leaf powder

$\mathrm{D}=65 \%$ Roasted Maize flour: $15 \%$ Roasted Soy-bean flour: $20 \%$ Moringa leaf powder.

\subsection{Minerals and Vitamin a Content of Soy-mumu Supplemented with Moringa Powder}

The mean scores for minerals and vitamin A contents as presented in Table 3 showed that there was significant difference $(\mathrm{P}<0.05)$ among all the samples. The iron, calcium, Zinc, potassium and vitamin A contents increased significantly $(\mathrm{P}<0.05)$ with increasing percentage of Moringa oleifera leaf powder. Increase in mineral content
(Zinc and Iron) was also reported by [14] when complementary food was formulated using malted maize, millet, and sorghum with groundnut and soybean. [9] also reported increase in mineral and vitamin A contents when maize-ogi was fortified with moringa leaf powder. The changes in the mineral and vitamin A contents of the SoyMитu supplemented with moringa leaf powder may be attributed to the high levels of iron, Calcium, Zinc, potassium and vitamin A contents in dried Moringa leaves [4, 2] and [11].

Table 3. Minerals $(\mathrm{mg} / 100 \mathrm{~g})$ and Vitamin A (mcg/100g) content of SoyMumu Products.

\begin{tabular}{lllllll}
\hline Sample & Fe & Ca & Zn & K & $\mathbf{I}_{2}$ & Vit. A \\
\hline A & $41.8^{\text {d }}$ & $384.6^{\text {d }}$ & $12.6^{\text {d }}$ & $165.7^{\text {d }}$ & $9.7^{\text {d }}$ & N.D \\
B & $52.3^{\mathrm{c}}$ & $484.1^{\text {c }}$ & $14.3^{\mathrm{c}}$ & $268.7^{\mathrm{c}}$ & $11.6^{\mathrm{c}}$ & $2.0^{\mathrm{c}}$ \\
C & $61.8^{\mathrm{b}}$ & $587.9^{\mathrm{b}}$ & $16.5^{\mathrm{b}}$ & $332.4^{\mathrm{b}}$ & $14.8^{\mathrm{b}}$ & $2.9^{\mathrm{b}}$ \\
D & $67.3^{\mathrm{a}}$ & $746.2^{\mathrm{a}}$ & $17.6^{\mathrm{a}}$ & $387.6^{\mathrm{a}}$ & $16.3^{\mathrm{a}}$ & $4.3^{\mathrm{a}}$ \\
L.S.D & 2.112 & 14.43 & 0.803 & 14.71 & 0.731 & 0.3301 \\
\hline
\end{tabular}

Values are means \pm S.D triplicate determinations. Means within each column not followed by the same superscript 
letters are significantly $(\mathrm{P}<0.05)$ different.

Key:

$\mathrm{A}=85 \%$ Roasted maize flour: $15 \%$ Roasted Soy-bean flour: $0 \%$ Moringa leaf powder.

$\mathrm{B}=75 \%$ Roasted maize flour: $15 \%$ Roasted Soy-bean flour:

$10 \%$ Moringa leaf powder.

$\mathrm{C}=70 \%$ roasted Maize flour: $15 \%$ Roasted Soy-bean flour: $15 \%$ Moringa leaf powder.

$\mathrm{D}=65 \%$ Roasted Maize flour: $15 \%$ Roasted Soy-bean flour: $20 \%$ Moringa leaf powder.

\subsection{Sensory Properties of Soy-mumu Supplemented with Moringa Powder}

Results of sensory characteristics; taste, flavour colour, texture and general acceptability showed that there were significant differences $(\mathrm{P}<0.05)$ in these sensory attributes among all the samples. For taste, sample A (control) received the highest score of 9 corresponding to like-extremely while sample D with 20 percent Moringa leaf powder had a score of 5 corresponding to neither like nor dislike.

For flavour, colour and texture, sample A (control) received scores of 8 for each. This corresponds to like-very much while sample A with 20 percent Moringa leaf powder received scores of 6 for the three characteristics and this corresponds to like slightly. However, there was no significant difference $(\mathrm{P}<0.05)$ between sample $\mathrm{B}$ and sample $\mathrm{C}$ with 10 and 15 percent Moringa leaf powder respectively in terms of taste, flavour, colour and texture.

For general acceptability, there were significant differences $(\mathrm{P}<0.05)$ among all the four samples, with the control sample without Moringa leaf powder having the highest score of 9 that corresponds to like extremely followed by sample B (having 10\% moringa leaf powder) with score of 7 which corresponds to like moderately and sample D with $20 \%$ Moringa leaf powder had the least score of 6 corresponding to like slightly. However, sample B with $10 \%$ Moringa leaf powder was rated very close to sample $\mathrm{C}$ with 15\% Moringa leaf powder; 6.56 (sample B) and 7.22 (sample C ). The increase in likeness for colour as the percentage of Moringa leaf powder decreased could be ascribed to the green colour of the soy-mumu products imparted by the chlorophyll content of the leaves while that of flavour could be attributed to the herbal flavour of the Moringa leaf powder.

Table 4. Sensory Scores of soy-mumu supplemented with moringa leaf powder.

\begin{tabular}{llllll}
\hline Sample & Taste & Flavour & Colour & Texture & $\begin{array}{l}\text { General } \\
\text { acceptability }\end{array}$ \\
A & $8.50^{\mathrm{a}}$ & $7.89^{\mathrm{a}}$ & $8.17^{\mathrm{a}}$ & $7.89^{\mathrm{a}}$ & $8.61^{\mathrm{a}}$ \\
B & $7.11^{\mathrm{b}}$ & $6.50^{\mathrm{b}}$ & $7.11^{\mathrm{b}}$ & $6.83^{\mathrm{b}}$ & $7.22^{\mathrm{b}}$ \\
C & $6.33^{\mathrm{b}}$ & $5.89^{\mathrm{b}}$ & $6.44^{\mathrm{b}}$ & $6.22^{\mathrm{b}}$ & $6.56^{\mathrm{c}}$ \\
D & $5.28^{\mathrm{c}}$ & $5.67^{\mathrm{b}}$ & $5.61^{\mathrm{c}}$ & $5.50^{\mathrm{b}}$ & $5.78^{\mathrm{d}}$ \\
L.S.D & 0.961 & 0.869 & 0.819 & 0.721 & 0.630 \\
\hline
\end{tabular}

Values are means \pm S.D triplicate determinations. Means within each column not followed by the same superscript letters are significantly $(\mathrm{P}<0.05)$ different.
Key:

$A=85 \%$ Roasted maize flour: 15\%Roasted Soy-bean flour: $0 \%$ Moringa leaf powder.

$\mathrm{B}=75 \%$ Roasted maize flour: $15 \%$ Roasted Soy-bean flour: $10 \%$ Moringa leaf powder.

$\mathrm{C}=70 \%$ roasted Maize flour: $15 \%$ Roasted Soy-bean flour: $15 \%$ Moringa leaf powder.

$\mathrm{D}=65 \%$ Roasted Maize flour: $15 \%$ Roasted Soy-bean flour: $20 \%$ Moringa leaf powder.

\section{Conclusion}

a. Addition of Moringa leaf powder to soy-mumu, had significant effect on the proximate composition of the product; there was significant decrease $(\mathrm{P}<0.05)$ in moisture and carbohydrate content and significant increase $(\mathrm{P}<0.05)$ in crude protein content, crude fat fibre and ash with increasing level of supplementation.

b. There was significant increase in the minerals $(\mathrm{Fe}, \mathrm{Ca}$, $\mathrm{Zn}, \mathrm{K}$ and $\mathrm{I}_{2}$ ) and vitamin A contents of the soy-mumu with increasing level of Moringa leaf powder supplementation.

c. About 10 grams of Soy-mumu can provide 76 and $89 \%$ of the recommended daily allowance (RDA) of iron for children, 1-3 years at 10 and $15 \%$ levels of supplementation respectively while 100 grams can provide 193 and $228 \%$ of the RDA of iron for pregnant women at 10 and $15 \%$ levels of supplementation respectively.

d. There was significant decrease in likeness for taste, flavour, colour, texture and general acceptability as the level of supplementation for Moringa leaf powder increased.

e. The general acceptability of all the products was high, with all the products having scores higher than 5 which is the minimum acceptable value on a nine point hedonic scale.

f. The soy-mumu supplemented with moringa powder at $10 \%$ and $15 \%$ should be adopted since most sensory scores are higher than six, to enhance maximum nutrients and keeping quality.

\section{References}

[1] Ingbian, E. K. and Adegoke, G. O. (2007). Nutritional Quality of Protein Enriched Mumu; a Traditional Cereal Food Product. International Journal of Food Science and Technology, 42: 476-481.

[2] Nwakalor, Chizoba. N. (2014). Sensory Evaluation of Cookies Produced from Different Blends of wheat and Moringa Leaf Flour, International Journal of Nutrition and Food Sciences, vol. 3 No 4 Pp 307-310.

[3] Freer, Kate (2009). Moringa: Natures Medicine Cabinet. Sanford Host Sunrise Books.

[4] Mishra, S. P.; Singh, P. and Singh, S. (2012). Processing of moringa leaves for Human Consumption. Indian Bulletin of pharmacology and life Sciences, vol.2 (1) pp28-31. 
[5] AOAC, (2005). Official Methods of Analysis, Association of Official Analytical Chemists. 18th Edition. Pp. 114-222. Washington, DC, USA.

[6] Ihekoronye, A. I. and Ngodddy, P. O. (1985). Integrated food Science and Technology for the Tropics. Mcmillan publishers ltd. Pp165-193, 139-148.

[7] Suzanne S. Nielsen (2009). Food Analysis. Fourth Edition. Purdue University, West Lafayette, IN, USA. Pp 96.

[8] Iwe, M. O. (2002). Handbook of Sensory Methods and Analysis. Rejoint Communication Services Ltd. Enugu Pp. 42-102.

[9] Genstat Release 7.2 DE (2009). Genstat Discovery Edition 3 VSN International Ltd. Association of Official Analysis, $17^{\text {th }}$ Edn. Washington DC; Association of Official Analytical Chemists (AOAC).

[10] Sengev, A. I., Abu, J. O. and Gernah, D. I. (2012).Effect of M. Oleifera Leaf Powder Supplementation on the Quality Characteristics of Wheat Bread. Int. Journal of Food Science and Nutrition. Vol. 1 (1): 1-5.
[11] Abioye Victoria Fumilayo and Aka, M. O. (2015). Proximate Composition and Sensory Properties of Moringa Fortified Maize- Ogi. Journal of Nutrition and Food Sciences 2015: Pp 1-4. Fourth Edition. Purdue university, West Lafayette, IN, USA. Pp 96.

[12] Nnam, N. M. (2000). Chemical Evaluation of Multi-mixes formulated from some Local staples for use as Complementary foods in Nigeria. Journal of plant foods for Human Nutrition Vol. 55 No. 3 pp 255-263.

[13] Aminigo, E. R and Akingbala, J. O. (2004) Nutritive Composition and Sensory Properties of Ogi Fortified with Okra seed meal. Journal of Applied Scinece and Environmental Management. Vol 8 No. 2.

[14] Anigo, K. M; Ameh, D. A.; Ibrahim, S and Danbauchi, S. S. (2010). Nutrient Composition of Complementary food gruels Formulated from Malted cereals, Soybeans and Groundnut for use in North-Western Nigeria. African Journal of Food Science Vol 4 No. 3, pp 65-72. 